\title{
INCIDENCE OF SOME SWEET POTATO VIRUSES, THEIR INTERACTION AND FREQUENCY UNDER FIELD CONDITIONS
}

Bondok, A. M. ${ }^{1}$; T. A. Moustafa*1; M. A. Rashed ${ }^{2}$ and F. M. Abo El-Abbas ${ }^{1}$

1- Department of Plant pathology, Faculty of Agriculture, Ain Shams Univ., Shoubra El-khemia, Cairo, Egypt

2- Department of Genetic, Faculty of Agriculture, Ain Shams Univ., Shoubra El-khemia, Cairo, Egypt

\begin{abstract}
During 2005-2006 a field survey of sweet potato viruses was carried out and 19216 plants growing in 42 feddans were examined. Symptoms suspected to be due to virus infection reached about $4.5 \%, 10 \%$ and $22 \%$ in Menoufiea, Damietta and Kalyoubia Governorates respectively. Symptomatic plants showed mosaic, yellowing or leaf curl accompanied with mosaic. Percentage of each pattern was varied according to the tested cultivar and location. One hundred and forty six symptomatic and sixty nine asymptomatic plants were collected and serologically analyzed by ELISA against the most wide spread sweet potato viruses (i.e. SPFMV, SPMMV, SwPLV, SPCFV, SPCaLV, SPMSV and SPCSV). Data revealed that $13 \%$ of asymptomatic and $68 \%$ of symptomatic plants was virus(s)-infected. SPFMV were detected in most infected plants either exhibiting symptoms or not. The virus existed either alone or in combination with the other viruses in double and mixed infections. Plants singly infected with this virus showed mild or no symptoms. Variable data were obtained with the other viruses. In contrast, SPMMV was found to be the lowest detectable virus. It was not detected in any single infection but tended to combine with SPFMV in double and mixed infections. Only three samples were infected with all tested viruses. Due to its wide spread, incidence in high frequency and problems facing its detection and diagnosis, some additional studies were carried out on the most predominant virus, SPFMV. It was identified by NCM-ELISA, immunosorbent electron microscopy and specific primers were used to ensure the identity.

keywords: Sweet potato viruses, Survey, Detection, NCM- ELISA. ISEM- PCR.

${ }^{*}$ Corresponding author
\end{abstract}

\section{INTRODUCTION}

Sweet potato, Ipomoea batatas (L.) Lam. is the third most important root crop in the world after potato (Solanum tuberosum L.) and cassava (Manihot esculenta Crantz) (Anonymous, 1998). During 2004, the global cultivated area with sweet potato was about 8,750,695 hectare that produced $129,403,827$ tons (Anonymous, 2005).

Sweet potato requires few inputs, making it appropriate for subsistence farmers with limited resources. Among the major starch staple crops, it has one of the highest rates of production per unit area per unit time (Woolfe, 1992). However, production is greatly constrained, particularly by viral diseases that cause great yield reduction ranging between 56 and 98\% (Ngeve, 1990 and Gibson et al., 1997).

Sweet potato feathery mottle potyvirus (SPFMV) occurs in Africa and in everywhere sweet potato is grown (Karyeija et al. 1998). Economic 
loss may be associated with external cracking and internal corkiness, making the tuberous roots unmarketable. However, there are few reports about this form of losses from Africa. In a small screen house trial in Uganda, a root yield of virus-free clone was about twice of the same inoculated colone (Gibson et al., 1997).

In Egypt the cultivated area increased from 9,130 to 10,000 feddans during 2000-2005 and the production was also increased from 249,548 to 300,000 tones respectively (Anonymous, 2005). Ishack et al. (2000) found that SPVD was the most prevalent virus disease in Egypt, which was detected during survey program (1997-2000) in the International of Potato Center in Gharbia.

The present study aimed to a) detect viruses infecting sweet potato in some productive area, b) determine the percentage of incidence of each virus and c) elucidate virus(s) frequencies and combinations in the infected plants.

\section{MATERIALS AND METHODS}

Survey of viruses infecting sweet potato was conducted in three productive Governorates i.e. Damietta, Menoufiea and Kalyoubia. A total of 19216 plants growing 42 feddans were examined with X- shape transects stretching between opposing corners of each field (Ateka et al., 2004). Number of tested plants was correlated with the area of each field. Number of plants exhibiting external symptoms suspected to be due to virus infections as well as type of symptoms was recorded for each selected field.

\section{Virus detection and identification}

One and half month after transplanting, 131 and 15 symptomatic, 64 and 5 asymptomatic sweet potato plants were collected from different locations at Kalyoubia and Damietta respectively. Collected plants were tested against the most wide spread sweet potato viruses i.e. Sweet potato feathery mottle virus (SPFMV), Sweet potato mild mottle virus (SPMMV), Sweet potato latent virus (SwPLV), Sweet potato chlorotic fleck virus (SPCFV), Sweet potato caulimo-like virus (SPCaLV) and sweet potato mild speckling virus (SPMSV). Detection of these viruses was carried out by nitrocellulose membrane enzyme-linked immunosorbent assay (NCM-ELISA) as done by Anonymous (2001), using standard kits obtained from the International Potato Center (CIP). Detection of sweet potato chlorotic stunt virus (SPCSV) was done by triple antibody sandwich (TAS)-ELISA in microtitre plates as described by Gibson et al., (1998). Percentages of infection with single double or multiple virus(s) were recorded.

\section{Detection and identification of SPFMV:}

Samples of Mabroka sweet potato plants found to be SPFMV infected (as tested by ELISA), were extracted, and their infectious sap was used to inoculate Ipomoea nil and I. setosa. Three weeks later, inoculated plants were used in the following experiments. 
Immunosorbent electron microscopy:

Identification was carried out by immunosorbent electron microscopy (electron transmission microscope, at Al-Azhar University, JEOL, JEM 1010; Japan) as described by Derrick (1973). The shape and size of the virus were determined by using the software analysis (Doc 2.11.005, soft imaging $\mathrm{GmbH}, 1986-1996)$.

Reverse transcription polymerase chain reaction (PT-PCR):

Total RNA was extracted from infected and healthy $I$. nil as well as from infected $I$. setosa and Mabroka sweet potato plants, according to Kern et al., (2005). Two specific primers were used i.e. the up stream primer SPFMV1 (5, -ATA GTG GGG GCA TCA TCA AAG G- 3.) and the down stream primer SPFMV 2 (5, - CCT AAA AGT AGG CAC TGC ATG G- 3,). RTPCR was carried out at $42{ }^{\circ} \mathrm{C}$ for $45 \mathrm{~min}$ in $10 \mathrm{mM}$ Tris- HCL buffer(pH 8.3) containing $4 \mu \mathrm{l}$ samples RNA, 20 pmol primers, $2.5 \mathrm{~mol}$ dNTPs, 30 units reverse transcriptase (RT), 5 units RNase, 1 unit Taq DNA polymerase. The reaction was predenaturated for $2 \mathrm{~min}$ at $95^{\circ} \mathrm{C}$, annealed for $30 \mathrm{sec}$ at $63^{\circ} \mathrm{C}$ and then extended for $1 \mathrm{~min}$ at $72^{\circ} \mathrm{C}$ for a total of 40 cycles in DNA thermal cycler (Perkin Elmer Modele 480, USA). PCR amplified products were separated by agarose gel electrophoresis. Aliquots of $10 \mu \mathrm{l}$ of PCR products were analyzed on 1\% agarose gel in TEB A buffer $1 \mathrm{X}$ (89 Mm Tris, $89 \mathrm{mM}$ borate and $2.0 \mathrm{mM}$ EDTA, pH 8.3) at 100 volt for $1 \mathrm{~h}$. The gel was stained with ethidium bromide at a concentration of $0.5 \mu \mathrm{l} / \mathrm{ml}$. DNA molecular weight marker was used to determine the size of RT-PCR amplified CDNA products of SPFMV. Bands of DNA were visualized on a UV transilluminator and photographed using documentation system (Bio/ Doc Analyze, Biometra)

\section{RESULTS AND DISCUSSION}

There is a lack of information about ecology aspects of sweet potato viruses under field conditions. Also, there are no available data on the interactions between different viruses affecting sweet potato in Egypt. In the present study, we tried to shed some light on the situation and interaction of sweet potato viruses in some productive areas in Egypt.

Accordingly, field survey was conducted at 42 feddans in three productive Governorates i.e. Kalyoubia, Damietta and Menoufiea using the common cultivar in each Governorate. Infected plants showed mosaic, yellowing and/or leaf curl accompanied with mosaic (Fig. $1 \mathrm{~A}, \mathrm{~B}$ and C). At some locations mosaic appeared on young leaves, while mild cholortic pattern was prominent on older leaves, Data in Table (1) revealed that, Kalyoubia has the highest percentage of infection $(21.95 \%)$, followed by Damietta $(9.75 \%)$ and then by Menoufiea (4.42\%). Among symptomatic plants the most prevalent symptoms in Kalyoubia was mosaic (68.58\%) followed by yellowing (31.41\%) and no leaf curl was observed on any plant. In Damietta, yellowing recorded $52.15 \%$ followed by leaf curl with mosaic $(47.89 \%)$ whereas in Menoufiea, leaf curl with mosaic raised to $83.33 \%$ followed by yellowing (16.66\%). No mosaic symptoms were observed neither in Damietta nor in Menoufiea. Incidence of different patterns varied greatly according to the cultivar and the location. The results were in parallel with that obtained by Mukasa et al. (2003) and Aritua et al. (2007). 

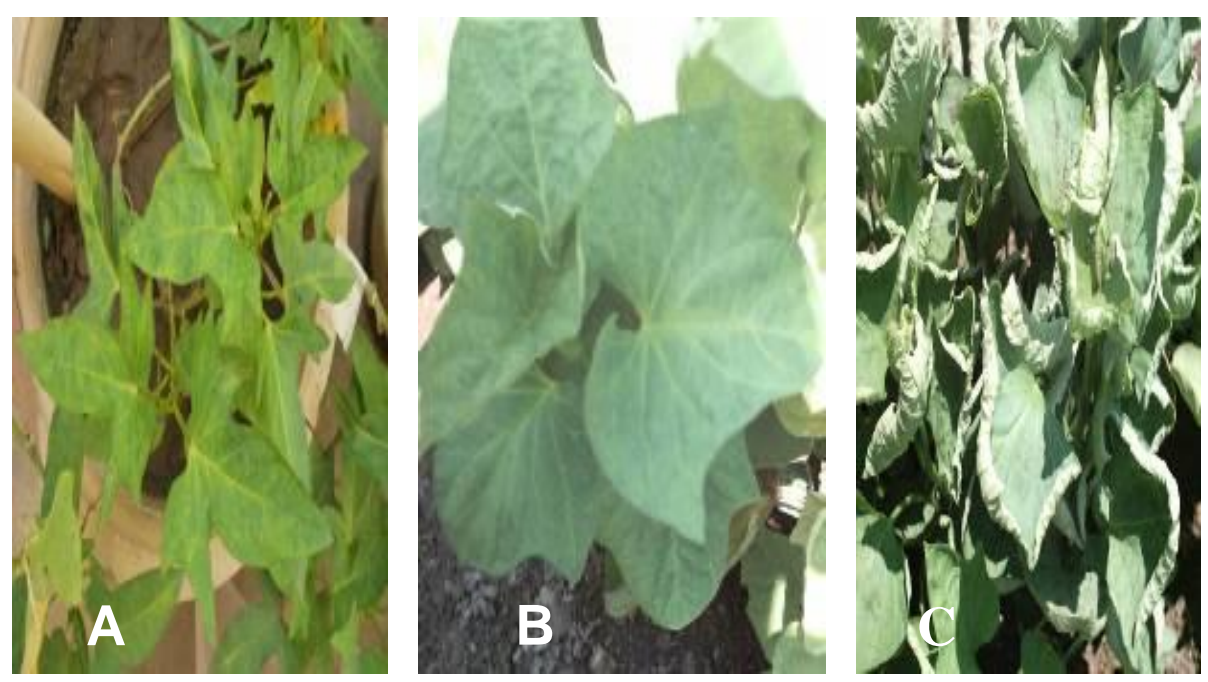

Fig. (1): External symptoms on some naturally infected sweet potato cultivars. (A): Abess showing mosaic. (B): Mabroka showing yellowing (C): Menoufiea 6 showing leaf curl \& mosaic.

Table (1): Percentages of external symptoms on sweet potato cultivars in three Governorates.

\begin{tabular}{|c|c|c|c|c|c|}
\hline \multirow{2}{*}{ Governorate } & \multirow{2}{*}{$\begin{array}{c}\text { Cultivar or } \\
\text { hybrid }\end{array}$} & \multicolumn{4}{|c|}{ Symptom incidence* } \\
\hline & & S/T & $M / S$ & $\mathbf{Y} / \mathbf{S}$ & $(\mathrm{LC}+\mathrm{M}) / \mathrm{S}$ \\
\hline $\begin{array}{r}\text { Kalyoubia } \\
\%\end{array}$ & Mabroka & $\begin{array}{c}191 / 870 \\
21.95\end{array}$ & $\begin{array}{c}131 / 191 \\
68.58\end{array}$ & \begin{tabular}{|c|}
$60 / 191$ \\
31.41 \\
\end{tabular} & - \\
\hline $\begin{array}{r}\text { Damietta } \\
\% \\
\end{array}$ & Abess & \begin{tabular}{c|}
$190 / 1948$ \\
9.75
\end{tabular} & - & \begin{tabular}{|c|}
$99 / 190$ \\
52.1 \\
\end{tabular} & $\begin{array}{c}91 / 190 \\
47.89\end{array}$ \\
\hline \begin{tabular}{|} 
Menoufiea \\
$\%$
\end{tabular} & M 6 & $\left|\begin{array}{c}726 / 16398 \\
4.42\end{array}\right|$ & - & $\mid \begin{array}{c}121 / 726 \\
16.66\end{array}$ & $\begin{array}{c}605 / 726 \\
83.33\end{array}$ \\
\hline $\begin{array}{l}{ }^{*} \text { Number of: } \\
S=\text { symptomatic } p \\
Y=\text { yellowing } \\
T=\text { tested plants }\end{array}$ & $M=r$ & & & & \\
\hline
\end{tabular}

\section{Detection and frequency of some sweet potato viruses}

Symptomatic (146) and asymptomatic (69) sweet potato plants were collected from the most two productive Governorates i.e. Kalyoubia and Damietta. Infected plants were analyzed serologically with NCM-ELISA against SPFMV, SPMMV, SwPLV, SPCFV, SPCaLV, SPMSV and TASELISA against SPCSV.

In Kalyoubia Governorate Table (2) 86 out of 131 symptomatic samples were found to be virus infected $(65.6 \%)$. Single, double and mixed infections represented $58 \%, 20.9 \%$ and $20.9 \%$ respectively. SPFMV was the most prevalent virus either in single $(66 \%)$, double $(88,9 \%)$ or in mixed $(100 \%)$ infections. These results are in harmony with those obtained by Ateka 
et al. (2004) who found that SPFMV was the most common and the most widespread virus in Kenya. In contrast, SPMMV was found to be the lowest detectable virus representing about $5 \%$ of all infected plants. In addition, this virus was not detected in any single infection and tended to combine only with SPFMV either in double and mixed infections. SPMSV tended also to combine more frequently with SPFMV either in double or mixed infections. SPFMV was detected in all mixed infections. All the seven tested viruses were detected in three samples only, representing about 3.5\%of all infected plants.

Table (2): Natural occurrence and frequency of seven viruses in diseased sweet potato plants grown under field conditions as indexed by NCM-ELISA

\begin{tabular}{|c|c|c|c|}
\hline & Frequency & of the tested virus & ses in single, double and mixed infections \\
\hline & Single & Double & Mixed \\
\hline Kalyoubia: & SPFMV(33) & SPFMV+SPMMV(2) & SPFMV + SPCSV + SPCaLV (1) \\
\hline & SPCSV(5) & SPFMV + SPCFV (2) & SPFMV + SPCaLV + SPMSV (2) \\
\hline & SwPLV(2) & SPFMV + SwPLV (4) & SPFMV + SPCaLV + SwPLV (1) \\
\hline & SPMSV(2) & SPFMV+ SPCaLV (2) & SPFMV + SPCFV + SPCaLV + SPMSV (2) \\
\hline & SPCFV(4) & SPFMV + SPCSV (2) & SPFMV + SPCaLV + SwPLV + SPMSV (1) \\
\hline & SPCaLV(4) & SPFMV + SPMSV (4) & SPFMV + SPCSV + SPCaLV+SWPLV+SPMSV (1) \\
\hline & & SwPLV + SPMSV (2) & SPFMV + SPCSV + SPMSV (1) \\
\hline & & & SPFMV + SwPLV + SPMSV (3) \\
\hline & & & SPFMV +SPMMV + SPMSV (2) \\
\hline & & & SPFMV + SPCFV + SPMSV (1) \\
\hline & & & All tested viruses(3) \\
\hline total & 5 & 18 & 18 \\
\hline Jamietta & SPFMV(5) & SPFMV + SwPLV (2) & SPFMV + SPCSV + SwPLV (6) \\
\hline
\end{tabular}

In Damietta Governorate, only three viruses (SPFMV, SwPLV and SPCSV) were detected (Table, 2). Thirteen out of fifteen plants were found to be infected $(86.6 \%)$. Single, double and mixed infection represented 38.4 , 15.3 and $46.2 \%$ respectively. .In accordance with results obtained with Damietta plants, SPFMV was found in all samples (single, double and mixed infections).

Regarding asymptomatic plants, 9 out of 69 plants were virus(s)infected, among these 9, 8 were singly infected with SPFMV and one was doubly infected with SPFMV +SPMSV infection. SPFMV was found in all infected plants, but without any external symptoms. Clark and Moyer (1988) and Gibson et al. (1997) reported that SPFMV caused mild or no symptoms in sweet potato when it found alone.

As shown in Table (3) SPFMV was detected in $54.8 \%$ of symptomatic sweet potato plants, representing the most prevalent virus. This virus was followed by SwPLV 17.1\%, SPMSV(16.4), SPCSV(13\%), SPCaLV (11.6\%), $\operatorname{SPCFV}(8.2 \%)$ and SPMMV(4.8\%). In symptomatic sweet potato plants, SPFMV was reported to occurrence in $67.5 \%$ by Mukasa et al. (2003) and in $74 \%$ by Ateka et al. (2004).

Sweet potato feathery mottle virus (SPFMV):

SPFMV-infected Mabroka sweet potato plants (as detected by ELISA) were used to isolate this virus. Infectious sap was extracted and used 
to inoculate 2 indicator hosts ( $I$. nil and $I$. setosa). Three weeks after inoculation, vein clearing and mild mosaic accompanied with malformation were observed on the new leaves. These symptoms are similar to those observed on the indicator hosts by Cadena-Hinojosa and Campbell (1981) and Moyer and Salazar(1989). However, identity of SPFMV was ensured by ELISA test. The inoculated indicator hosts were used as a source of the virus in the following studies.

Table (3): Incidence of different viruses in symptomatic sweet potato plants grown in Kalyoubia and Damietta as indexed by NCMELISA

\begin{tabular}{|c|c|c|c|c|c|c|c|c|c|c|c|c|c|c|c|}
\hline \multirow{2}{*}{ Governorate } & \multirow{2}{*}{$\begin{array}{c}\text { No. of } \\
\text { samples }\end{array}$} & \multicolumn{2}{|c|}{ SPFMV } & \multicolumn{2}{|c|}{ SPCSV } & \multicolumn{2}{|c|}{ SPMMV } & \multicolumn{2}{|c|}{ SPMSV } & \multicolumn{2}{|c|}{ SwPLV } & \multicolumn{2}{|c|}{ SPCalV } & \multicolumn{2}{|c|}{ SPCFV } \\
\hline & & + & $\%$ & + & $\%$ & + & $\%$ & + & $\%$ & + & $\%$ & + & $\%$ & + & $\%$ \\
\hline Kalyoubia & 131 & 67 & 51.1 & 13 & 10 & 7 & 5.3 & 24 & 18.3 & 17 & 13 & 17 & 13 & 12 & 9.1 \\
\hline Damietta & 15 & 13 & 86.6 & 6 & 40 & - & - & - & - & 8 & 53.3 & - & - & - & - \\
\hline Total & 146 & 80 & 54.8 & 19 & 13 & 7 & 4.8 & 24 & 16.4 & 25 & 17.1 & 17 & 11.6 & 12 & 8.2 \\
\hline
\end{tabular}

+ = virus infected plants

\section{Immunosorbent electron microscopy(ISEM)}

EM-serology is highly sensitive and have become an important method for virus identification. (Derrick, 1973; Milne and Luisoni, 1975). This test was done using partially purified SPFMV. Negatively stained preparations (after trapping with specific SPFMV antibody with $2 \%$ uranyle acetate) were examined. Electron micrographs revealed the presence of flexuous particles with about $830 \mathrm{~nm}$ in length (Fig. 2). Shape and size of these particles are in accordance with those reported by some authors(McLean 1959; Campdell et al. 1974; Nome et al. 1974; Moyer and Kennedy 1978 and Cali and Moyer, 1981). They mentioned that, particle length of SPFMV ranged between 800 and $850 \mathrm{~nm}$ in the infected plants.

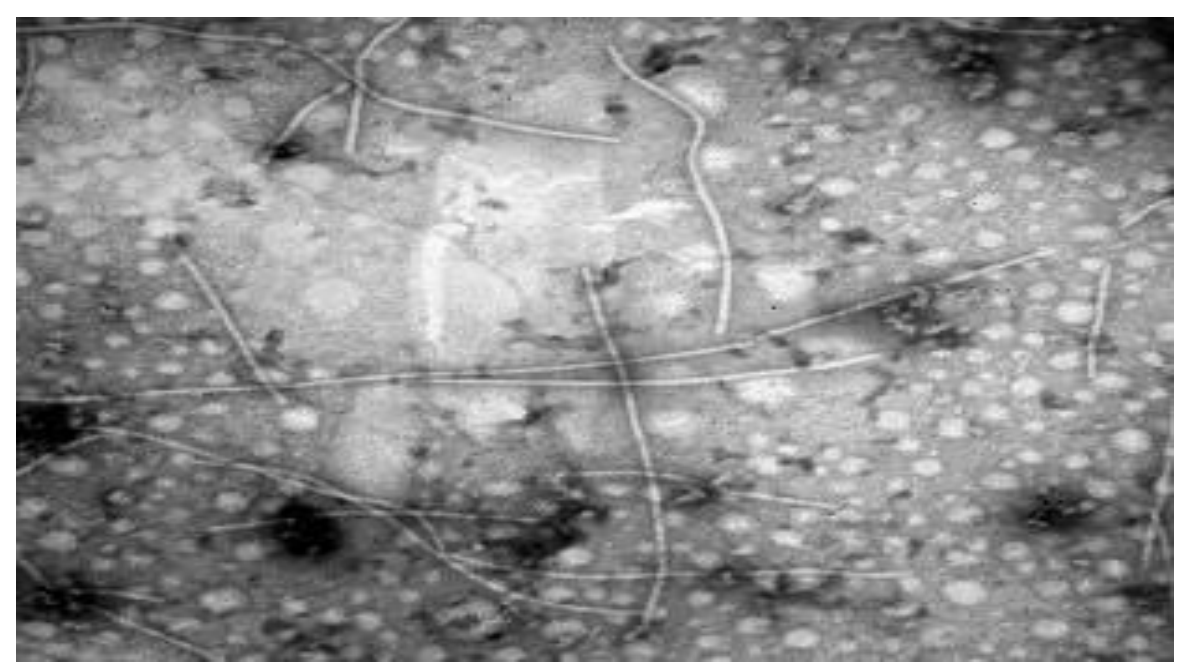

Fig. (2): Electron micrograph of partially purified virus preparation stained with uranyl acetate, $x=60000$. 
Reverse transcription- polymerase chain reaction (RT-PCR):

The total RNAs prepared and purified from infected- I nil, I setosa and Mabroka sweet potato plants as well as from healthy I nil plants were reverse transcripted using one step PCR mix as mentioned before. This reaction was done by using the specific primers for coat protein gene of SPFMV. The up stream primer SPFMV1 was corresponded to nucleotides 202 to 223 whereas the down stream primer SPFMV2 was complementary to basses 591 to 612 of the viral RNA as mentioned by Jeong et al. (2003). Both primers (SPFMV1 \& SPFMV2) successfully amplified the cDNA Fig.(3). The size of PCR product amplified from infected plants was $411 \mathrm{bp}$. This was in agreement with the expected size calculated from the position of the primers and also as published for nucleotide sequence of coat protein gene. No signal was detected in the negative controls (non infected plants).

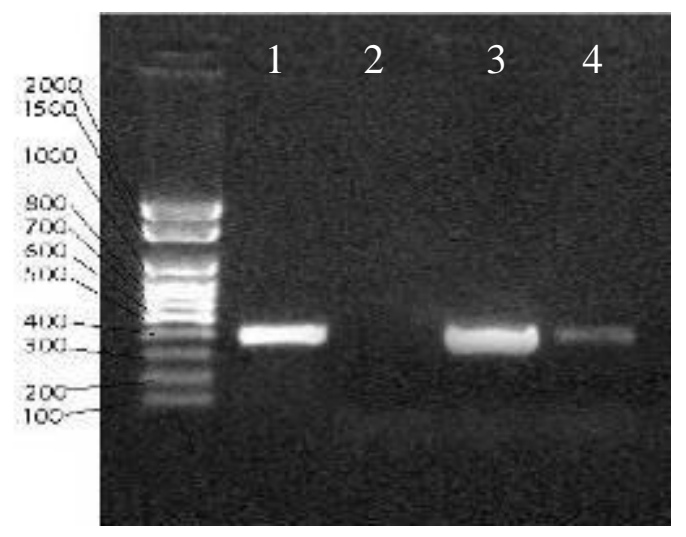

Fig (3): Agoras gel electrophoresis( $1 \%$ ) showing the results of RTPCR products, using SPFMV1 and SPFMV2 primers to amplify the full length(411 bp),using RNA extracted from infected Ipomoea nil (lane 1), healthy I nil (lane 2), infected Ipomoea setosa (lane3), infected sweet potato Mabroka (lane 4) M: DNA Molecular Weight Marker (Bioron).

This result was in agreement with that of Jeong et al. (2003) who described RT-PCR protocol using two specific 22- mer primers located in coat protein gene of SPFMV the up stream primer SPFMV1(5'-ATA GTG GGG GCA TCA TCA AAG G-3')and the down stream primer SPFMV2(5'CCT AAA AGT AGG CAC TGC ATG G-3')\}. A 411 bp PCR- product was detected in virus infected plants but not in healthy ones.

\section{REFERENCES}

Anonymous (1998). FAO production Year Book for 1996. Food and Agriculture Organization of the United Nation, Rome, Italy. pp. 91-92. (c.f. Mukasa et al., 2003).

Anonymous (2001). Techniques in plant virology in CIP. Training Manual Version: Lima, Peru: International Potato Centre. 
Bondok, A. M. et al.

Anonymous (2005). FAO. http://faostat.fao.org/DesktopDefault.aspx? pagelD $=r$ r \&lang=en

Aritua,V., Bua,B., Barg, H., Vetten, J., Adipala, E .and Gibson,W. (2007). Incidence of five viruses infecting sweet potatoes in Uganda; the first evidence of sweet potato caulimo-like virus in Africa. Plant pathology 56: 324-331.

Ateka, E.M., Njeru, R.W., Kibaru, A.G., Kimenu, J.W., Barg, E., Gibson, R.W. and Vetten, H.J. (2004). Identification and distribution of viruses infecting sweet potato in Kenya. Annals of applied Biology 144: 371379.

Cadena-Hinojasa, M.A. and Campbell, R.N. (1981). Serologic detection of feathery mottle strains in sweet potatoes and lpomoea incarnate. Plant Dis. 65: 412-414.

Cali, B.B and Moyer, J.W. (1981). Purification, serology, and particle morphology of two russet crack strains of sweet potato feathery mottle virus. Phytopathology 71:302-305.

Campdell, R.N., Hall, D.H. and Mielins, N.M. (1974). Etiology of sweet potato russet crack disease. Phytopathology 64: 210-218.

Clark,C.A. and Moyer, W. (1988). Compendium of Sweet Potato Diseases. The American phytopatological society. Minnesota, USA.74pp.

Derrick, K.S. (1973). Quantitative assay for plant viruses using serologically specific electron microscopy. Virology 56: 652-653.

Gibson, R. W., Mpembe, I., Alicai, T., Carey, E. E., Mwanga, R. O. M., Seal, S. E., and Vetten, H. J. (1998). Symptoms, etiology and serological analysis of sweet potato virus disease in Uganda. Plant Pathology 47:95-102.

Gibson, R.W., Mwanga, R.O.M., Kasule, S., Mpembe, I. and Carey, E.E. (1997). Apparent absence of viruses in most symptomless field grown sweet potato in Uganda. Annals of Applied Biology 130: 481-490.

Ishack, J., Bekheit, H., Ibrahim, L., El-Bedewy, R. and Abo El- Abbas, F. (2000). Occurrence of sweet potato virus disease in Egypt: Detection and epidemiological aspects. Fifth Triennial Congress of the African Potato Association. Pp.35(Abstr.)

Jeong, J.H., Chakrabarty, D., Kim, Y.S., Eun, J.S., Choi, Y.E. and Paek, K.Y. (2003). A simple detection of sweet potato feathery mottle virus by reverse transcription polymerase chain reaction. J. Plant Biotechnology 5:283-286.

Karyeija, R.F., Gibson, R.W. and Valkonen, J.P.T. (1998). The significant of sweet potato feathery mottle virus in subsistence sweet potato production in Africa. Plant Dis. 82: 4-15.

Kern, A.J., Chaverre, M.E. and Dyer, W.E. (2005). Dicamba- responsive genes in herbicide- resistant and susceptible biotypes of Kochina (Kochia scopania). Weeds Science 53:139-145.

McLean, D. D. (1959). Some aphid vector-plant virus relationships of the feathery mottle virus of sweet potato. Journal of Economic Entomology 52: 10571062

Milne, R.G. and Luisoni, E. (1975). Rapid high-resolution immune electron microscopy of virus preparations. Virology 68: 270-274. 
Moyer, J.W. and Kennedy, G.G. (1978). Purification and properties of sweet potato feathery mottle virus. Phytopathology 68: 762-767.

Moyer, J.W. and Salazar, L. F. (1989). Virus and virus-like diseases of sweet potato. Plant Dis. 75:451-455.

Mukasa, S.B., Rubaihayo, P.R. and Valkonen, J.P.T. (2003). Incidence of viruses and virus-like diseases of sweet potato in Uganda. Plant Dis. 87:329-335.

Ngeve, J. M. (1990). Yield stability and yield depression in sweet potato cultivars susceptible to the sweet potato virus disease. J. Hortic Sci. 65:225-230.

Nome, S.F., Shalla, T.A. and Petersen, L.J. (1974). Comparison of virus particles and intracellular inclusions associated with vein mosaic feathery mottle and russet crack diseases.Phytopathol. Z. 79: 169- 178.

Woolfe, J. A. (1992). Sweet Potato, an Untapped Food Resource. Cambridge University Press, New York. 643 PP.

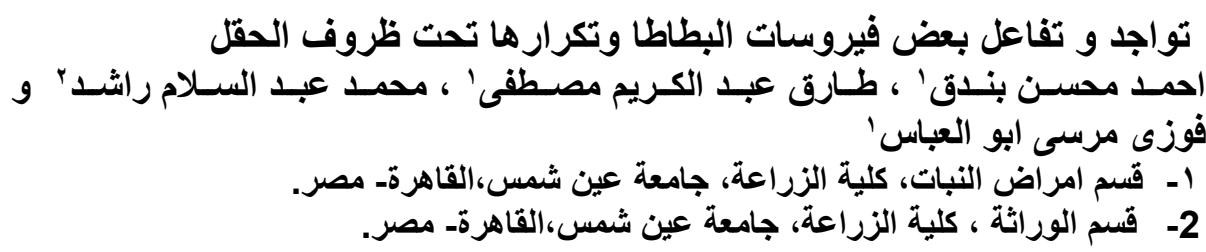

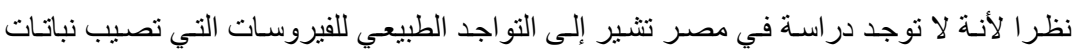

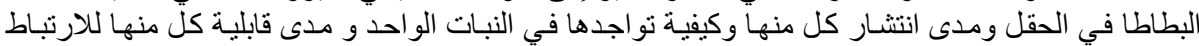

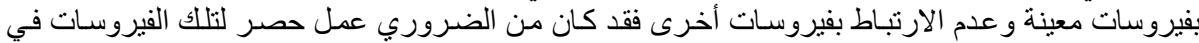

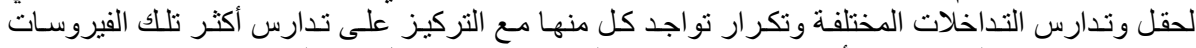

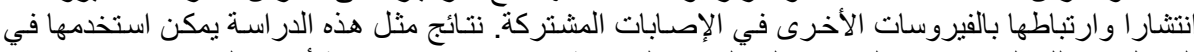

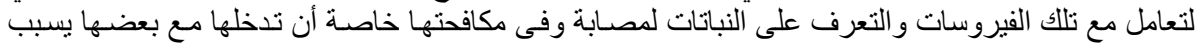

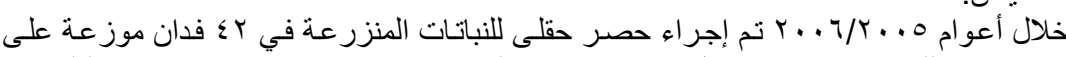

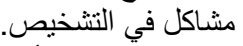

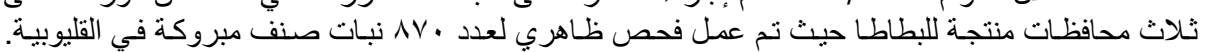

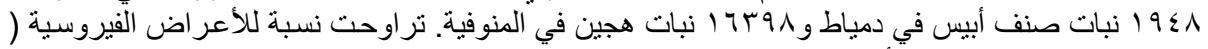

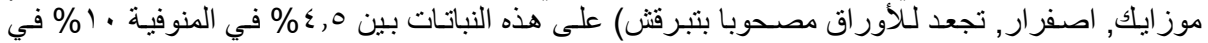

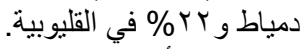

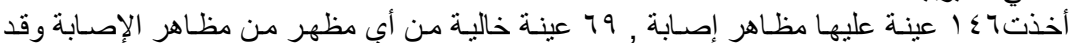

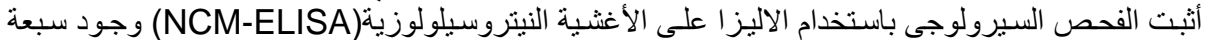

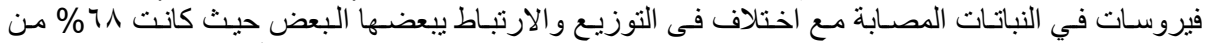

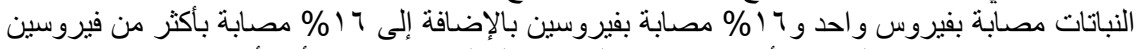

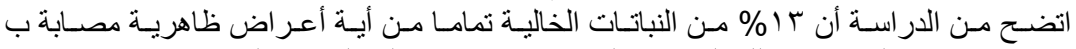

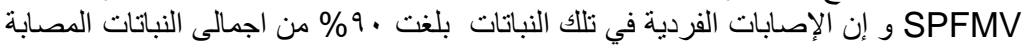

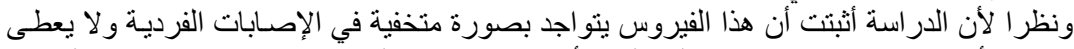

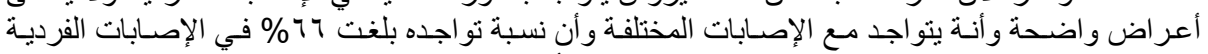

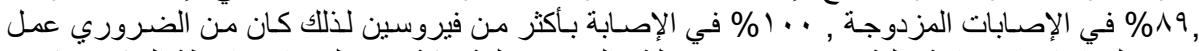

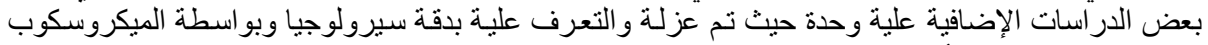

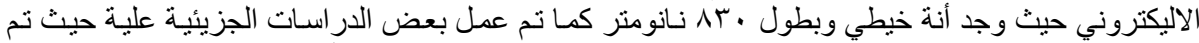

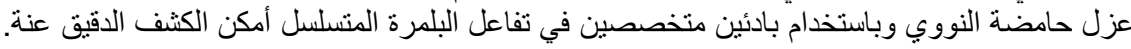

